\title{
SOUND RULES AND ADMINISTRATION IN ARBITRATION
}

\section{J. Noble Braden $\dagger$}

\section{Hazards of Arbitration Without Rules and Administration}

No lawyer would think of practising in a court without first ascertaining and learning its rules of practice and procedure. Still less would one consider appearing before a court which had no rules; and imagine the embarrassment of the practitioner if that omniscient official, the clerk of the court, suddenly vanished from the scene. The practice of law would perhaps be more exhilarating, but it would certainly be an unreliable, unpredictable and unsatisfactory proceeding. Yet arbitration without regulation and without an adequate agency to administer these procedural regulations is just as unreliable.

Modern laws aiming to promote the use of arbitration have been criticised on the ground that an unusually large number of arbitration cases have found their way into the courts. It is argued by critics adopting this attack that in place of litigation alone, the modern arbitration acts simply substitute arbitration plus litigation. The criticism may have some merit, but a large percentage of the cases which have reached the courts were those in which the parties had adopted no rules of procedure, or rules that were inadequate, and had provided no administration for the arbitration proceeding. It is submitted that had adequate rules and administration been available, many of these cases would not have been the subject of litigation.

A committee composed of leading members of the New York Bar reported recently that in a survey of one thousand lawyers, selected at random, approximately three-quarters of them were favorable to arbitration but used it infrequently because of their lack of familiarity with it. ${ }^{1}$

Arbitration is not a panacea; neither is any other reform. Who would attempt to embark upon a new business venture without becoming acquainted with its customs and its possibilities? Who would attempt seriously to play a game without first learning the rules? An examination will show that to embark on an arbitration without rules is no less hazardous than to undertake any other venture under similar circumstances.

Arbitration is more than a substitute for trial-more than a method of determining business disputes. ${ }^{2}$ To serve its true purpose, it must provide expert judges to determine the facts speedily and dispose inexpensively of

$\dagger$ Secretary, American Arbitration Association; collaborator, Code of Arbitration: Practice and Procedure (ig3i); The Practice of Commercial Arbitration (ig28).

I. Bulletin II, Special Committee of Lawyers, American Arbitration Association, April 1933. Reported favorable to arbitration 735, unfavorable 72, non-committal 234, total I94I members of New York City Association of the Bar.

2. Cf. Isaac, Two Views of Commercial Arbitration (I927) 40 HARv. L. Rev. 929. 
the controversy. It must be so conducted that there will be no further litigation between the parties, and none of the rancor or enmity that so frequently results from a lawsuit. Some arbitrations fall short of this. Many have failed in the past. The object of this paper will be to attempt to indicate the means whereby satisfactory arbitration can be obtained and the speed, privacy, economy, convenience, goodwill and final settlement of a controversy be assured.

". . . [The] arbitration process and the arbitration law are two different things." 3 The process is dependent upon the law for its authority, but the law does not concern itself primarily with the details of the process. It is true that, from time to time, the courts have indicated, in special instances, a procedure to be followed; but even this can generally be varied by agreement of the parties. ${ }^{4}$ Even the modern arbitration acts concern themselves mainly with the enforcement of the proceedings and the award, and are, on the whole, enabling and not regulatory legislation. It is obvious, therefore, that proper control of the procedure is dependent, in the main, upon the agreement of the parties, and not upon the law.

Since arbitration is privately administered and the law does not concern itself with procedure, a mere provision for arbitration will not ensure that the proceeding will result in the advantages expected when the agreement is made. Sharp practices on the part of the less responsible, and desire for gain, which sometimes causes a strain upon responsibility, are not always the cause of the difficulty. Even with the best intentions, parties who are at odds and who are attempting to resolve a controversy may honestly disagree on the procedure to follow, and arbitrators with no rules to guide them may become engulfed in hopeless difficulties.

$A$ and $B$ agree to arbitrate. Shall there be one or three arbitrators? If three, how shall they be appointed? When shall the appointments be made? $A$ appoints an arbitrator. $B$ fails to do so or $B$ does appoint one and the appointees cannot agree upon a third. $A$ appoints an impartial arbitrator. $B$ appoints a biased one. How shall this inequality be overcome? An arbitrator resigns. How shall the vacancy be filled? When shall the hearing be held, and where? Who shall set the time and place when the demands of the parties conflict? $A$ desires to be represented by counsel. $B$ objects and contends that no counsel should be present. Shall witnesses be sworn? When and for what cause may an adjournment be granted? May arbitrators summon witnesses on their own initiative? May commodities be examined in the absence of the parties? May counsel sum up? May briefs be filed? How shall the hearing be closed? May it be reopened, and, if so, upon what

3. Phillips, The Paradox in Arbitration Law: Compnlsion as Applied to a Voluntary Proceeding (1933) 46 HARv. L. Rev. 1258, 1264.

4. Cf. Phillps, A Practical Method for the Determination of Business Fact (1934) 82 U. OF PA. L. Rev. 230. 
grounds? When must the award be made? To whom shall it be delivered? What compensation shall be paid the arbitrators and by whom?

These questions, whose number might be greatly increased, are neither theoretical nor unusual. They have been in many instances the subject of controversy, and the result has often been a failure by the parties to receive the justice which they sought from arbitration. For example, in New York an appeal was taken to the Court of Appeals for a decision as to the method of filling a vacancy in a board of arbitrators. ${ }^{\bar{J}}$ In other instances parties have gone to courts to determine whether stenographic notes of arbitration proceedings shall be taken, whether counsel may be present at hearings, whether an adjournment should be granted, and who shall pay the expenses of the witnesses. ${ }^{6}$

The courts are sometimes reluctant to hear and help parties in such difficulties, as was indicated by the Supreme Court of Washington in refusing to pass upon the question of whether an award was made within a reasonable time, when the parties had provided no definite time within which it should be rendered. The court's statement may be considered typical of the judicial attitude: "The contract of arbitration is merged in the tribunal which it creates. . . Unless they expressly fix a time limit, they can no more say how rapidly it shall proceed than they can control the number of questions that shall be asked." $\tau$

With these facts in mind, it is well to remember that so long as there are parties with questionable ideas as to responsibility and fairness, and so long as there are lawyers who will aid their clients by unfair tactics, advantage will be taken of the gaps which present themselves. Therefore arbitration, to be effective, must be guided by rules adopted in advance-rules which mark the path to follow and safeguard against lapses in the proceedingsrules which prevent both parties and arbitrators from acts of omission or commission that, in the eyes of the law, will nullify the arbitration and the award.

\section{Advantages of Carefully Drawn Rules and Good Administration}

The simplest method of avoiding the difficulties indicated wonld be the inclusion of detailed provisions in the contract covering every possïile contingency which might arise in arbitration. Occasionally contracts are found setting forth, at some length, procedural provisions. Experience has shown,

5. E. Arthur Tutein, Inc. v. Hudson Valley Coke \& Products Corp., 249 N. Y. 84, 162 N. E. 592 (1928).

6. Anderson Trading Co., Ltd. v. Brimberg, II9 Misc. 784 , I97 N. Y. Supp. 289 (Sup. Ct. I922) (stenographers); Matter of Kayser (Skulrich), N. Y. L. J., Jan. 14, I925, at I4I7 (counsel); In re Matter of Picker, I30 App. Div. 88, 114 N. Y. Supp. 289 (Ist Dep't I909) (adjournment).

7. See Dickie Mfg. Co. v. Sound Constr, and Eng. Co., 92 Wash. 316, I59 Pac. 129 (Ig16). Cf. Couperie Belge Americaine, S. A., N. Y. L. J., Jan. I9, 1934, at 307. 
however, that these are ineffective and generally fail to take into account the very contingencies which later give rise to disputes. ${ }^{8}$

To cover completely the type of contingency which is likely to arise in an arbitration, and to set forth in detail a complete arbitration procedure, would require a document so lengthy that its use would be impracticable in the ordinary business contract. The primary concern of a commercial contract is not the arbitration provision, and therefore it is not feasible to set forth arbitration procedure at length. Furthermore, none but counsel experienced in arbitration procedure would be capable of drawing up such an agreement properly, even if it were feasible; and were it drawn, there would arise the difficulty of assuring adequate administration. The American Institute of Architects has for years provided in its standard specifications a provision for arbitration with certain procedural details. But in many inștances when the procedure set forth in the contract was followed, and the president of the local bar association was called upon to appoint the third arbitrator, it was found either inexpedient to ask him to do so, or, when requested to act, he refused for reasons of his own. The only possible way to remedy the lapse was to make a new agreement, or apply to the courts for relief. It is evident that some other method must be found to provide for procedure, anticipate contingencies, and remedy lapses. The best method is to include, by reference, the rules of some established body providing for the procedure and administration of arbitration. ${ }^{9}$ The contract then will no longer merely provide for arbitration, but for arbitration under definite rules of procedure and administration by an experienced agency.

The widespread use of arbitration in England is due in no small part to the custom of proceeding under the arbitration rules of various guilds and trade associations. ${ }^{10}$ Like our business law here, arbitration in England is the result of customs established by early English merchants. In fact, as is noted by Blackstone, it was the success of arbitration in the trade associations in England that influenced Parliament to enact arbitration statutes. ${ }^{11}$

In no small measure the considerable use of arbitration in New York is likewise due to the influence of the New York State Chamber of Commerce, which has maintained arbitral rules and facilities since I768. Many

8. Cf. E. Arthur Tutein, Inc. v. Hudson Valley Coke and Products Corp., 249 N. Y. 84, 162 N. E. 592 (1928).

9. See Codf of Arbitration: Practice and Procedure (ig3i) 46, 205 for Standard Arbitration Clause. See alsc the corresponding clauses of the Chamber of Commerce of the State of New York and Silk Association of America.

io. See Rosenbaum, Commercial Arbitration in England, Am. Jud. Soc., Bull. XII (IgI6) \$7. Cf. Simpson, "A very large proportion of the business disputes of England never come into the courts at all, but are adjusted by tribunals established within the various trade associations and exchanges."

II. "An experience having shown the great use of these peaceable and domestic tribunals, especially in settling matters of account, and other mercantile transactions, which are difficult and almost impossible to be adjusted on a trial at law; the Legislature has now established the use of them, as well in controversies where causes are depending, as in those where no action is brought." $3 \mathrm{BL}$. CoMm. *17. 
other trade associations have had established arbitration facilities since early time. Provisions for arbitration were contained in the original by-laws of the Philadelphia (I8oI) and Boston ( 1836 ) Boards of Trade.

Today there are rules available throughout the entire United States. In some instances they are the rules of functionalized trade associations; in others, of bodies such as chambers of commerce, the American Arbitration Association, etc., devoting their main efforts to arbitration, or having committees charged with the responsibility of conducting arbitral proceedings. The lawyer thus has available many established procedures from which to choose. The large number of them and the importance of many of the organizations sponsoring them are substantial evidence of their necessity and worth. ${ }^{12}$

It is interesting to note that the need for adopting definite arbitration procedure was clearly recognized by the diplomats of both Russia and Germany when the Treaty of I925 was drafted. In addition to providing for the arbitration of commercial disputes between the business agencies of Russia and the business men of Germany, a special annex was attached to the treaty setting forth rules of procedure and administration for such arbitrations. ${ }^{13}$

Established procedure will insure an impartial and expert administration of the arbitration and a final settlement of the dispute. The risks previously indicated will be eliminated and arbitration will prove to be speedy, inexpensive, friendly, and expert in the determination of a controversy.

Unlike a trial at law, where the administration is standardized by practice, set forth by statute, and conducted by paid public officials, arbitration is administered by mutual agreement of the parties. When engaged in the settlement of a controversy, parties can hardly be expected to agree on what should be done. Notices must be sent, hearing rooms provided and clerical details attended to. Arbitrators, selected because of their business experience, and whose primary interest is not arbitration, should not be expected or required to perform these functions. By adopting established rules adequate administration will be assured. In addition, the integrity of the organization encourages confidence and respect in the proceeding, and guarantees the impartial and expert administration of arbitration. This neutral agency further provides an information bureau, the "court clerk", to resolve any difficulties or questions that may arise as to what to do and when to do it. It arranges for the various steps in the proceeding - arrangements which are sometimes difficult and technical, and which may be made almost impossible for a party-litigant to complete, because of the feeling engendered by the existing controversy.

I2. A complete collection of arbitration rules of trade and commercial bodies in the United States is contained in Year Book on Commerctal Arbitration IN THE U. S. (I927).

13. I INTERnational Year Book on Civil aNd Conimercial Arbitration (I928) 243. 
Rules, even the most elementary, will set forth some sort of a procedural guide. But adequate rules will provide for the institution of the proceedings, appointing arbitrators, assuring the impartiality of arbitrators, filling vacancies, notice of hearing, the plan of the hearing, the reception of evidence, the function of the administrative agency, the closing and the reopening of the hearing, the time for making the award and for its delivery to the parties. The rules, of course, provide exact time limits and directions for the performance of the acts required of the parties, the arbitrators, and the administrative agency.

In most instances, the very fact that this detailed procedure has been provided will insure the carrying through of the arbitration. Experience of years has shown that where the way is laid out, only a very small percentage of parties to controversies will fail to follow it. But there are occasions when, despite the most carefully planned procedure, a party will fail or neglect to take the required steps. For example, rules provide that an arbitrator shall be appointed within seven days after notice. A party fails to act. The administrative agency, under proper rules, remedies the lapse by exercising the power conferred upon it by the rules and appoints the arbitrator.

The rules provide that arbitrators shall be impartial. As will hereafter be demonstrated, such provision is of paramount importance for a successful proceeding. One party claims that the other has appointed a biased arbitrator. The administrative agency, acting under the rules and the standards laid down therein, will pass upon the challenge and, when necessary, remove the arbitrator, filling the vacancy thus caused in the manner set forth by the rules.

Thus, by adopting proper procedure and providing for careful administration, the two can be combined whenever necessary to remedy lapses and secure a prompt and impartial disposition of the controversy. Occasional difficulties will arise concerning proper interpretation of the rules, but well drawn rules invariably provide for a committee of the administrative body to interpret them and settle such questions without recourse to the courts. Of course, there are many interpretations which can be made by the arbitrators during the hearing; and these, like those of the administrative committee, will be upheld by the courts. ${ }^{14}$

The heterogeneous decisions of the courts and requirements of arbitration statutes, whose confusion increases the difficulties of parties, counsel and arbitrators, will be simplified by comprehensive rules. ${ }^{15}$ Steps insisted upon by statute and those necessitated by decisions of the courts, can be set forth clearly in the rules, and the likelihood of their being overlooked and neglected by the parties is thus minimized. ${ }^{16}$

14. Fudickar v. Guardian Mut. Life Ins. Co., 62 N. Y. 392 (1875).

15. For example of heterogeneous decisions see Phillips, supra note 3.

15. For example of heterogeneous 1 I452 (oath). Cf. California Walnut Growers Assn. v. Miller, N. Y. L. J., Feb. 18, 1926, at 2018 ; Hiltl Co., Inc. v. Bishoff, II9 Misc. 572, I97 N. Y. Supp. 6I7 (Sup. Ct. 1922). 
But rules should do more than merely codify the law. A greater purpose can be served by avoiding decisions which are not in accord with business custom and practice, or with the best arbitration practice for the needs of the trade. For example, in many disputes an ex parte examination or test may be of the utmost importance in arriving at a fair decision. In some trades, an examination of disputed merchandise without the presence of the parties is considered the very heart of the arbitration proceeding. ${ }^{17}$ In other types of disputes an examination of the books of the parties and a report directly to the arbitrators thereon is of prime necessity. Properly drafted rules will secure the sanction of the courts for such procedure. ${ }^{1 s}$

The impression must not be created that rules isolate the proceeding from the law; for just as the entire arbitral process is dependent upon the law for its authority, rules have the support of, and follow, the law. The successful use of rules in arbitration is in no small measure due to the friendly attitude and support afforded by the law. In some instances legislatures have enacted special statutes legalizing the arbitration rules of commercial bodies. ${ }^{19}$ The courts, too. have held repeatedly that rules previously agreed upon to furnish a guide for the conduct of an arbitration nust be followed by the parties. ${ }^{20}$

The cost of unregulated, casual arbitration has been at times the cause of much adverse comment. Rules, however, will fix arbitration fees and administration expenses, or provide a method therefor. Thus costs can be determined in advance and kept within reasonable bounds.

The privacy of arbitration is one of its great advantages. The public airing of private matters, trade secrets, confidential operating costs and the like, to which may be added the loss of prestige and goodwill, attendant upon the publicity of a court trial, can be prevented by rules which insure that only the parties and the arbitrators may be present at the hearing and that all will respect the confidence of the proceeding. ${ }^{21}$

In addition, it is essential and indeed of paramount importance, that the arbitrators appointed to determine the controversy be not only skilled in the particular profession or industry concerned, but that they be absolutely

17. See Rules of the National Association of Importers of Hides \& Skins, also Rules of the United States Shellac Importers Association, Inc.

18. See Robins Silk Co. v. Consolidated Piece Dye Works, 224 App. Div. 83, 229 N. Y. Supp. 500 (Ist Dep't 1923), aff'd, 25I N. Y. 87, 167 N. E. I8I (I929); Finsilver, Still \& Moss, Inc. v. Goldberg, Maas \& Co., Inc., 253 N. Y. 382, I7I N. E. 579 (1930) ; Wenger \& Co. v. Propper Silk Hosiery Mills, 239 N. Y. 199, 146 N. E. 203 (1924).

I9. N. Y. Laws I862, c. $359, \$ \$ 5$ to 7 (Produce Exchange); N. Y. Laws $186 \mathrm{r}$, c. 25I (Chamber of Commerce of the State of New York).

20. Marine Transit Corp. v. Dreyfus, 284 U. S. 263 (I932); Finsilver, Still \& Moss, Inc. v. Goldberg, Maas \& Co., Inc., 253 N. Y. 382, 17I N. E. 579 (1930).

2x. Section One of proceeding during the hearing of the rules of the Association of Food Distributors, Inc. (1934) provides: "Before entering upon the duties of their office, the arbitrators shall take and subscribe to an oath in the form prescribed. This oath, in addition to binding the arbitrators to a faithful performance of their duties, shall also stipulate that except as to the parties themselves they shall 'hold in strict confidence every feature and circumstance of the arbitration'." 
impartial. ${ }^{22}$ A properly conducted administrative agency and good rules will provide this. Left to themselves, parties will frequently appoint partisan arbitrators, causing delay in the selection of the third arbitrator, and frequently nullifying the entire proceeding as a result of bias. More interested in securing advocates than experts, the parties will rarely select arbitrators on the basis of their technical knowledge. Even if parties endeavor to procure impartial experts, each will frown upon the other's choice and fear their bias. Unsatisfactory arbitration can often be traced to the poor selection of arbitrators.

Practically all bodies having arbitration rules have established panels of arbitrators-men skilled in the trade, selected because of their standing, integrity and experience, who have agreed to serve as arbitrators after weighing the duty and responsibility involved. Membership on such a panel is recognized in the industry as a place of honor and responsibility. As a result of their experience on such panel, the arbitrators add to their technical knowledge of the trade a judicial experience and temperament. With the advancement of arbitration in the United States, and its recognition as an established method of settlement of business controversies, the need for established panels of arbitrators is everywhere recognized. ${ }^{23}$

As a result of the availability of such a panel, the practice of selecting advocates is discouraged, and the parties willingly cooperate in the mutual appointment of impartial, skilled arbitrators. Various methods are provided to assure this result, and in them the administering body plays an important role. ${ }^{24}$ Around this appointment of impartial expert arbitrators from a panel revolves the entire arbitration set-up of many industries, and to it can be traced the satisfaction of the parties with the friendly, speedy and economical proceedings resulting therefrom.

Objection may be made that as the result of building up this complete procedure, arbitration is being robbed of the flexibility which is one of its outstanding virtues. This is not so if the rules are properly drawn. All good rules provide for interpretation and amendment, as well as for the adoption of special rules to govern unusual circumstances and to meet emer-

22. ". . . the practice of arbitrators of conducting themselves as champions of their nominators is to be condemned as contrary to the purpose of arbitrations, and as calculated to bring the system of enforced arbitrations into disrepute. An arbitrator acts in a quasi-judicial capacity, and should possess the judicial qualifications of fairness to both parties, so that he may render a faithful, honest, and disinterested opinion." Matter of American Eagle Fire Ins. Co. v. New Jersey Insurance Co., 240 N. Y. 398, 405, I48 N. E. 562, 564 (I925). panels.

23. See Year Book on Commercial Arbitration (1927) for numerous provisions for

24. Under the Rules and Practice of the American Arbitration Association a duplicate list of arbitrators is submitted to the parties and they are allowed seven days to return the list with the names of the arbitrators objected to crossed off and if desired the remaining names numbered in the order of preference. Almost invariably a sufficient number of names remain on both lists so that there is no difficulty in securing three arbitrators upon which the parties have agreed. See Form iIr Cone. of Arbitration Practice and Procedure (I93I) 255 . 
gencies. Rapidly changing business conditions make this a prime requisite, and the impartial arbitration committee of the administering body, thoroughly familiar with trade conditions and with a knowledge of arbitration procedure, can act to make such changes when necessary. The spirit of goodwill created by sound arbitration rules and skillful administration leads the parties to waive technical legal requirements whenever circumstances necessitate such waiver. Adequate rules temper the necessary rigidity of the proceeding with an essential flexibility to meet changing conditions. It may be suggested that it is unwise or dangerous to give these broad powers to a trade or commercial organization lest they be misused. So may any power; but the aggrieved party may always resort to the courts to prevent any violation of his fundamental rights. ${ }^{25}$ Again, the arbitration record of trade and commercial organizations of more than one hundred years is ample assurance of their impartial administration of arbitration. ${ }^{26}$

\section{Rules Must Be Skillfully Drazen and Well Administered}

Arbitration even with good rules cannot always be carried through to a successful conclusion. As has been demonstrated elsewhere, the authority of the law is needed at times to compel recalcitrants to perform a promise to arbitrate. To secure such compulsion the arbitration agreement must meet the requirements of the law. The effect of the best rules may sometimes be lost because of the lack of legal enforceability of the arbitration agreement itself. But the rules should perform a most important function by being predicated upon an agreement that will provide the maximum amount of legal enforceability possible.

Even assuming that the arbitration agreement has been carefully drawn, rules, or the lack of them, cannot change the common law doctrine of many states that agreements to arbitrate future disputes are revocable. ${ }^{27}$ The rules used in such instances should be drawn so as to require the execution of a submission agreement after the dispute has arisen, which will meet the requirements of the existing law. A well drawn submission agreement of an existing dispute is specifically enforceable in almost every state. ${ }^{28}$

The legal requirements for an enforceable submission agreement are technical and vary in almost every state. For example, in Delaware and Maryland, a friendly suit must be commenced, the submission agreement made part of the pleading, and a rule entered thereon in order to secure

25. Finsilver, Still \& Moss, Inc. v. Goldberg, Maas \& Co., Inc. 253 N. Y. 382, I7I N. E. 579 (1930); Kanter v. The Edward Bloom Co., I44 Misc. 602, 259 N. Y. Supp. 46 (Sup. Ct. 1932).

26. Cf. Cohen, Commerctal Arbitration and the Law (igi8).

27. See United States Asphalt Ref. Co. v. Trinidad Lake Petroleum Co., 222 Fed. Io06 (S. D. N. Y. 1915).

28. In all states except South Dakota and Oklahoma under statutes generally varying as to requirements, agreements to arbitrate existing disputes may be enforced. 
enforceability. In other states the submission agreement must be formally acknowledged according to rigid formulæ. ${ }^{29}$

On the other hand, the existence of a legally enforceable arbitration agreement in many states will make court action for specific enforcement unnecessary. Compulsion of arbitration should be used only when other means fail, as it tends to create the illwill which arbitration is particularly designed to prevent. In these states a proper arbitration agreement will permit an ex parte proceeding when necessary. But this possibility will not be available unless rules have been adopted and an agency created to prevent the errors which will occur in such a proceeding. For example, the rules will provide for the appointment of arbitrators by the agency when a party fails to act.

Enforcement by court proceeding or under rules may at times be impossible, due to an inadequate or carelessly drawn arbitration agreement. In an almost incredible number of instances arbitration has been defeated or rendered ineffectual because the parties were unable to agree upon what they had previously agreed to arbitrate; and if the matter was referred to the courts, it was often determined they had made an agreement to arbitrate which in its terms had been contemplated by neither. ${ }^{30}$

It is not the purpose of this paper to discuss the proper drafting or legal enforceability of arbitration agreements; and furthermore it has been well demonstrated elsewhere that there is "a curious admixture of statute upon statute" and a host of technical decisions that must be observed. ${ }^{31}$ It is obvious that with this great variation of legal requirements rules must likewise differ, depending upon the state in which the arbitration is sought; or, if general rules are drawn, provision must be made to adapt them when necessary. In situations where legal enforceability cannot be relied upon, the paramount purpose of rules is to assure consent and voluntary performance.

Arbitration agreenents may also be enforced by means outside and apart from arbitration statutes. Members of a trade association may be bound to arbitrate by provisions in their by-laws and such provisions are legally enforceable. Not only will the arbitration agreement be enforced but disciplinary action by the association, such as the imposing of fines or expulsion from membership, will be upheld by the courts. ${ }^{32}$

Where an arbitration agreement is not specifically enforceable, trade association by-laws can furnish the basis ipon which to found an enforceable

29. For a comparison of statutory requirements see Sturges, Commercial Arbitrations AND AwARds (1930).

30. See Young v. Crescent Development Co., 240 N. Y. 244, I48 N. E. 510 (1925); Marchant v. Mead-Morrison Mfg. Co., 252 N. Y. 284,169 N. E. 386 (1929).

31. Phillips, Rules of Law or Laissez Faire in Commercial Arbitration (I934) 47 Harv. L. REv. 590 .

32. See Evans v. Chamber of Commerce of Minneapolis, 86 Minn. 448 , 9 N. W. 8 (1902); Gerseta Corp. v. Silk Association of America, 200 App. Div. 890, 192 N. Y. Supp. 370 (Ist Dep't I922). 
arbitration; and even in states where agreements are enforceable, trade association provisions should not be overlooked. Where arbitration is designed for use within a given trade, by-law provisions will be important in supplementing statutory enforcement by disciplinary action of the trade association, and by giving stimulus to arbitration where such provisions are not contained in the contract between the parties. Many codes under the NRA provide for arbitration, although the method of enforcement is not at this time clear. ${ }^{33}$ The ultimate aim of good rules, however, is not to provide compulsion but on the contrary, by means of carefully worked out procedure and administration, to build such satisfactory arbitration practice as to make compulsion unnecessary. Goodwill is an inevitable result of good procedure and administration. ${ }^{34}$ The writer's actual experience in several thousand arbitrations has demonstrated to him that adequate rules, and the confidence inspired by the integrity of the administrative agency, with impartial arbitrators provided by an established panel, are such as to make legal compulsion unnecessary. The full cooperation of the parties in an earnest endeavor to complete the arbitration becomes an every day occurrence. But the rules must be well drawn, and the proper atmosphere must be created, or the opposite effect may result.

\section{Necessity of Procedure Conforming to Law and Custom}

There is a potential danger in the use of rules, arising from the probable assumption on the part of the parties to an arbitration that the rules will contain everything that the law requires. If any essential requirement of the law is omitted, the result may be fatal to the arbitration; it is essential that the rules require the performance of any acts made necessary by the law. Legal requirements under modern arbitration laws are few, but failure to meet any one of them may invalidate the arbitration. As has been previously indicated, there are differences in practically all states. All laws must be examined. In New York, for example, arbitrators must be sworn in a prescribed manner. Neither the Pennsylvania nor the federal statutes contain such a requirement. In Pennsylvania witnesses must be sworn before testifying-New York has no such provision. Awards must be acknowledged in New York-Pennsylvania does not require acknowledgment. ${ }^{35}$

It is not enough merely to take the statutes into account, since the courts in interpreting the statutes have read into them unmentioned requirements. Thus, for example, in order to have an enforceable arbitration under the New York Act, a demand must be made and a controversy, as technically defined by the courts, must be shown to exist. ${ }^{36}$ In addition, the courts have

33. See Phillips, Commercial Arbitration under the N. R. A. (1933)! I U. of CHr. L. REv. 424 .

34. See Kellor, Arbitration in the New Industrial Soctety (i934).

35. For a comparison of the requirements of state arbitration laws, see YeAR BooK oN Commercial Arbitration in the Civited States (1927) Annex. I.

36. California Walnut Growers' Assn. v. Mfiller, N. Y. L. J., Feb. I8, I926, at page 20r8; Frittl Co., Inc. v. Bischoff, II9 Misc. 572, 197 N. Y. Supp. 617 (Sup. Ct. 1922). A form for a demand for arbitration appears in Code of Akbitration: Practice ano Procedure (193I) 207. 
indicated that common law rules supplement the statutes, and these in many instances are conflicting. Fortunately the courts insist on most of such requirements only when the parties have not otherwise provided. Therefore, with appropriate rules, a procedure in accordance with business custom and necessity may be provided.

It has been held by the Court of Appeals of New York that arbitrators may not conduct an ex parte examination of merchandise. ${ }^{37}$ In some trades it is expected and essential that arbitrators examine merchandise without the presence of the parties, and even without knowledge of their identity. The Liverpool Cotton Association maintains a list of twenty-four arbitrators, and appoints an arbitrator upon application of the parties without disclosing his identity. The arbitrator examines the cotton without knowing the names of the parties, as all distinguishing marks must be removed before the examination.

In addition to circumventing decisions that are contrary to trade practice, rules should provide for the arbitration to take into account recognized trade customs, and thereby assure that the arbitration will be held in accordance with the usage of the trade. In the fur import trade in the United States, it is the custom to require that at least Io\% of the shipment shall be retained unopened when a question of quality is to be arbitrated. In other trades, custom prescribes a definite procedure for securing samples to be used by the arbitrators in passing on quality. Numerous other instances of special trade customs might be cited; but, as they differ from trade to trade, it is necessary in drafting good rules to consult not only legal authority but the advice of experienced members of the trade.

While it is necessary for rules to provide for trade customs and practice, it by no means follows that parties must use rules limited to a particular industry to obtain this advantage. Properly drawn general rules, $i$. e., rules provided by an organization serving business generally, will take them into account. Such general rules are a necessity in controversies involving intertrade disputes. One party will frequently decline to submit a controversy to the arbitration board set up by the other party's trade organization. The various branches of the woolen business will readily submit any difference concerning the manufacture of the yarn into cloth to their trade body. The clothing manufacturer likewise prefers his own association. Both, however, will agree to the general arbitration rules and administration of a neutral agency. ${ }^{38}$ Such agency should obviously be one without an interest in the proceeding other than the performance of its function; and while a trade association may and should provide arbitration for its members, a way should

37. Berizzi Co, v. Krausz, 239 N. Y. 315, 146 N. E. 436 (1925).

38. See Rules of the American Arbitration Association for the Wool and Garment Trades (1933), adopted by National Association of Wool Mfrs., Clothing Mfrs. Research Board, N. Y. Clothing Mfrs. Exchange, Industrial Council of Cloak, Suit and Skirt Mfrs., Merchants' Ladies Garment Association, Textile Finishers Association, Textile Adjusters Association (Greater New York), Mutual Adjustment Bureau of Cloth and Garment Trades. 
be left open to them to use some other agency in the event that the dispute concerns a member and a non-member. General rules should be chosen unless the functionalized rules are clearly necessary to provide the type of arbitration needed in the individual case.

\section{Advantages of an Impartial Administrative Agency}

Administration has frequently troubled the users of arbitration. Under early common law practice, the arbitrators made their own rules of procedure and administered them. In Scotland there was a "Clerk of the Submission", having a knowledge of the arbitration law, who was appointed by the arbitrators to assist them with procedural matters. It may be suggested that there is no need of an administrative agency where the parties are both represented by attorneys. Nevertheless, opposing attorneys are frequently unable to agree upon what steps to take. And, as has been previously noted, many members of the bar admit that they are as yet uninformed, due to "an habitual inertia" of the legal profession to aid in the guidance of such activities. $^{39}$ An examination of the lower court decisions appearing in the New York Law Journal, the very number of which is a reflection of arbitrations held with poor administration and procedure, in many instances, confirms this fact.

The importance of administration cannot be overestimated. Procedure and administration are so interwoven that unless there is proper administration the arbitration may often fail. Good administration will check the proceeding with the rules as it goes forward, and prevent both parties and arbitrators from committing or omitting acts whose effect would be to invalidate the award. Administration is like the traffic policeman on a busy avenue. $\mathrm{He}$ is there to straighten out snarls, keep traffic moving, act in emergencies, and enforce the rules when necessary. A brief review of an administered arbitration will demonstrate the truth of this analogy.

$A$ and $B$ enter into a contract providing for arbitration under the rules of a named administrative agency. A dispute arises. $A$, or his attorney, makes a demand for arbitration on $B$, the form having been secured from the administrative agency. The administrative agency, upon receipt of a copy of the demand, communicates with the parties to learn their wishes in regard to the type of arbitrators to be submitted; or perhaps sufficient information is given in the demand so that the experienced administrative agency will know the type of arbitrators to suggest. The dispute may be in the construction industry, between a contractor and sub-contractor. The administrative agency submits a list of arbitrators made up of three parts, one of general contractors, another of sub-contractors, and a third of men familiar with building generally. These latter may be neither contractors nor sub-

39. Mass. L. Q. (Feb. I923) 6I. 
contractors, but architects, real estate operators, or title insurance company officials. Or perhaps the dispute is in the clothing industry, and the administrative agency suggests clothing manufacturers, textile manufacturers, clothing retailers, or merchandising managers of large stores. In such lists the importance of the standing panels of arbitrators, which has been previously emphasized, is obvious. At the expiration of a given period, if arbitrators have not been appointed, the administrative agency makes the appointment. It communicates with the arbitrators, learns their wishes in reference to the date of hearing, and arranges with the parties, or their attorneys, a date mutually convenient. Arbitration is essentially a friendly proceeding, and no one is suddenly called before a tribunal unless he is recalcitrant and has refused to cooperate in the arrangements for the proceeding.

The administrative agency supplies not only a place for the hearing but a hearing room suitable for the purpose intended. It sends formal notices of the hearing to all concerned. A party may desire a subpœna; under the New York Arbitration Law it is required that the arbitrators, or a majority of them, sign such subpona. It is the administrative agency's task to arrange to secure these signatures with the least possible inconvenience to the arbitrators, and to see that the document is sent to the parties promptly so that it may be served well in advance of the hearing. At the commencement of the hearing, the agency makes certain that the arbitrators take their oath when required under the prevailing law, and presents the file of the proceedings to them.

During the course of the hearing the arbitrators may express a desire to visit the building, or to have tests made of the merchandise, without the presence of the parties. Where the rules have not already provided for this, the agency secures the waivers or stipulations made necessary by the law, in order to carry out the arbitrators' wishes. Good administration creates a proper atmosphere, and the parties cheerfully cooperate in taking such steps as the agency may suggest for accomplishing the wishes of the arbitrators. This is not surprising, for the parties would not have selected the particular agency in the first place had they not previously been satisfied with its integrity and standing.

All through the proceeding a clerk, expert in arbitration, is present to keep track of the exhibits, to assist the parties and the arbitrators in all possible ways, and to insure that the arbitration will be conducted in accordance with the law. When the proceeding has been closed the administrative agency continues to act, perhaps to receive the briefs filed by counsel and transmit them to the arbitrators. By having this neutral agency through which the parties communicate with the arbitrators, there is eliminated the chance that by some direct communication to the arbitrators by only one of the parties an act will be committed which may invalidate the award. When 
the arbitrators have reached their decision, the appropriate form is supplied by the administrative agency; it is completed as required by law, and then formally transmitted to the parties. Even after the award has been forwarded to the parties, the function of the agency does not end. The administrative agency has kept a complete file of the original documents used in the proceeding, and can supply these to the parties and counsel, should they be necessary, in any subsequent court proceeding, to confirm the award and enter judgment. ${ }^{40}$

All through the proceeding the administrative agency must, by its impartial conduct of the proceeding, and its relations with the parties, preserve and foster a spirit of goodwill and cooperation. As has been indicated, the preservation of goodwill is one of the most important phases of arbitration. Where the arbitration has been well administered, the losing party will usually pay the award without any further legal proceeding. ${ }^{11}$ It is a matter of general knowledge that arbitration is extensively used in England, and that commercial cases are notably absent from the calendar of the British courts. A survey of the English situation shows that this is due to the procedure and efficient administration of arbitration by the committees of boards of trade and commercial organizations of that country. ${ }^{42}$

\section{Some Tests for Arbitration Rules}

The essential elements of good rules and administration, as well as the necessity therefor, have been demonstrated. The utilization of such elements will insure a satisfactory arbitration process. In drafting arbitration rules, or considering the adoption of such rules, a check of these essential elements will be most important. In addition, however, it will be necessary to make other tests.

An arbitration may logically and chronologically be divided into four parts, and the sufficiency of the rules judged in reference to their ability to provide this logical procedure. The four steps in an arbitration are: the institution of proceeding; the appointment of the arbitrators; the hearing; and the award. When rules insure these chronological steps on the way to a satisfactory arbitration, the first requirement of good rules has been met.

Arbitration, as a process controlled and conducted by the parties, the arbitrators, and an administrative agency, imposes certain duties and obligations and confers certain rights upon each. A study of numerous successful arbitrations and of arbitration rules that have been proved by experience to forms.

40. See Code of Arbitration: Practice and Procedure (r93i) 253-284 for arbitration

4I. An inquiry directed to those who had obtained awards in the American Arbitration Tribunal in two calendar years disclosed that in $88 \%$ of the cases awards were carried out without confirmation by the courts and in only $6 \%$ was there any contest of the award.

42. See Rosenbaum, op. cit. supra note 9. 
provide satisfactory arbitration enables one to determine the general rights and duties of parties, arbitrators, and the administrative agency.

The parties have the following rights and duties: The parties instituting proceedings shall, when necessary, make a written demand for arbitration. They shall state concisely the matter submitted to arbitration. They may agree upon the number of arbitrators and may either appoint them or designate the method of their appointment. They shall remove from office any arbitrator who is not impartial. They may fill any vacancy in the officc of arbitrator. They may be represented by counsel. They shall be entitled to a speedy, private hearing and be permitted to present all proofs and witnesses material to the controversy. They may be present when any evidence is offered to the arbitrators and may cross-examine witnesses.

The arbitrators have the following duties and responsibilities: They shall be impartial. They shall, when required, take an oath to perform the duties of their office. They shall arrange for the submission of proofs, at a hearing or otherwise, as soon as practicable. They shall conduct hearings in an orderly manner and permit the parties to present all their pertinent proofs and witnesses. They shall receive no evidence except in the presence of the parties and of each other, unless the parties otherwise agree. They. shall close the hearings only after ascertaining that no further pertinent and material evidence is to be presented. They may postpone or reopen hearings, before the award is rendered, for good cause shown. They may interpret the rules adopted by the parties for the conduct of the proceeding and may render all decisions by a majority vote. They shall make the award free from interference of the parties or of the administrative body and shall limit it to subject matter submitted. The award shall be in writing and be signed by the arbitrators, or a majority of them, and shall then be delivered to the parties.

The administrative agency has the following powers: It shall institute only such proceedings as are referred to it by the parties. It may designate the number of arbitrators if the parties fail to do so. It may appoint the arbitrators if the parties fail to do so. It may remove from office any biased arbitrators if the parties fail to do so. It may fill any vacancy in the office of arbitrator when the parties fail to do so. It shall notify all arbitrators of their appointment. It shall perform such clerical duties and issue such notices as may be properly assigned to it by the arbitrators or by the parties. It may furnish hearing rooms. It shall provide arbitrators with a clerk familiar with arbitration procedure. It shall notify the parties of all proceedings and all action taken. It shall assure the parties of privacy in the proceedings and preserve the records and documents submitted. It shall limit the cost of the proceeding by establishing a fixed schedule of fees. 
An examination of arbitration rules with the chronological steps borne in mind, and a determination that the rights and duties of the parties, the arbitrators, and the administrative agency have been clearly and precisely set forth, should provide the means of determining a set of rules that will lead to a successful arbitration; provided, however, that the administrative agency sponsoring the rules is an experienced and responsible body.

Rules that meet these requirements, and are sponsored by an experienced and responsible agency, will provide a procedure in accordance with the arbitration law. It must be remembered that the foundation of the arbitration process is constructed upon this procedure. In addition, such rules will be drawn in accordance with trade custom, or be so drawn that special rules to follow individual trade custom may be easily adopted.

When it is recognized by the lawyer and the business man that good procedure and administration are as vital to the securing of satisfactory arbitration as they are to the administration of justice in our courts, and when such rules and administration become customary in arbitration, then the condition which now obtains in England, where courts are practically free of commercial controversies, will also prevail in the courts of the United States. 